\title{
Our Experience in Skin Grafting and Silver Dressing for Venous Leg Ulcers
}

\begin{abstract}
ADELAIDA AVINO ${ }^{1}$, CRISTINA-NICO LETA COZMA ${ }^{1,2 *}$, ANDRA-ELENA BALCANGIU-STROESCU ${ }^{3,4}$, MARIA-DANIELA TANASESCU5,6, DANIELA GABRIELA BALAN ${ }^{4}$, DELIA TIMOFTE ${ }^{3,7}$, SILVIA MARIA STOICESCU ${ }^{8}$, CRISTIAN-SORIN HARIGA ${ }^{2}$, DORIN IONESCU ${ }^{5,6}$ 1Prof.Dr.Agrippa Ionescu Clinical Emergency Hospital, Department of Plastic and Reconstructive Surgery,7 Ion Mincu Str., 011356, Bucharest, Romania

${ }^{2}$ Carol Davila University of Medicine and Pharmacy, Faculty of Medicine, Discipline of Plastic and Reconstructive Surgery, 37 Dionisie Lupu Str., 020021, Bucharest, Romania

${ }^{3}$ Emergency University Hospital Bucharest, Department of Dialysis,169 Splaiul Independenei, 050098, Bucharest, Romania ${ }^{4}$ Carol Davila University of Medicine and Pharmacy, Faculty of Dental Medicine, Discipline of Physiology, 37 Dionisie Lupu Str., 020021, Bucharest, Romania

${ }^{5}$ Emergency University Hospital Bucharest, Department of Nephrology, 169 Splaiul Independenei, 050098, Bucharest, Romania ${ }^{6}$ Carol Davila University of Medicine and Pharmacy, Faculty of Medicine, Department of Medical Semiology, Discipline of Internal Medicine I and Nephrology, 37 DionisieLupu Str., 020021, Bucharest, Romania

'Dialysis Center Sema Parc Bucharest, 319 Splaiul Independenei 060044, Bucharest, Romania

${ }^{7}$ Carol Davila University of Medicine and Pharmacy, Faculty of General Medicine, Obstetrics-Gynecology, Polizu Hospital,

38-52 Polizu Str., 011062, Buchares, Romania

Silver is used nowadays in numerous domains, from the manufacture of jewelery to the medical field. It has also healing properties being used as a wound dressing that creates an aseptic environment. The management of wound healing using a skin grafts often requires hospital admission, a period of immobility, attentive donor site wound care and pain control. A prospective study was realized to evaluate the silver dressing efficacy in treating lesions after skin grafting of chronic ulcers. Our evaluation showed good results with an accelerated re-epithelialization.
\end{abstract}

Keywords: chronic wounds, silver dressing, skin grafting

Venous ulcer is responsible for more that $70 \%$ of chronic ulcers of the lower limb [1]. It decreases patients' quality of life and the productivity atwork places, being weakening and sore [2]. It is a severe complication of the chronic venous insufficiency [1], which is challenging to cure. Chronic ulcers are defined as lesions that do not heal in three months. These wounds are becoming a public health issue due to the fact that they affect a high percentage of patients with diabetes and arterial disease [3]. Other causes of chronic ulcers are arterial insufficiency, diabetes mellitus and trauma [1]. The main risk factors that can determine venous leg ulcers are old age, female sex, obesity, trauma, immobility, deep vein thrombosis, phlebitis [4], malnutrition [5], poor hygiene, intravenous drug abuse and varicose veins [2].

The diagnosis is indicated by the clinical examination. The venous ulcers are usually irregular, with well-defined borders [1] and located over bony prominences, in the distal portion of the lower limbs [6]. In general, the surrounding skin presents acute or chronic lipodermosclerosis. The wound is also associated with varicose veins and ankle edema [1]. Characteristically, in the base of the ulcer there is granulation tissue and fibrin. A yellowish exudate can be noticed on the wound dressing. Even if, venous ulcers are not painful, they are commonly reccurent [6]. The most important complications of chronic venous ulcers that must be highlighted are osteomyelitis and sporadically neoplastic transformation. Frequently, chronic ulcers are associated with colonization of bacteria, such as Staphylococcus aureus, Pseudomonas aeruginosa, Enterobacter and Escherichia coli [ 7].

The management of treatment of the venous ulcers is based on healing the wound and avoiding recurrence [1].

\section{Experimental part}

A case control series of thirty patients with venous ulcers were treated in the Plastic Surgery Department of
Emergency Clinical Hospital Prof. Dr. Agrippa Ionescu during a period of six months. Inclusion criteria were chronic venous ulcers older than 3 months. Patients with uncontrolled glycemia, with hemoglobin value less than $12 \mathrm{mg} / \mathrm{dL}$, with allergy or hypersensitivity to silver sheets and pregnant women were notincluded in the study. Local ethical agreement and informed consent of the patient were obtained.

At admission usual blood tests and bacterial wound cultures were realized. Prior the surgery, the wounds were cleaned daily with betadine soap and saline solution and antiseptic dressings were applied until the granulation tissue appeared. Antibiotic therapy was started according to the positive results of wound swab cultures.

The patients were divided in two groups, of fifteen patients each. The surgical intervention, described by the excisional debridement and skin grafting, was performed for all the patients, after the formation of the granulation tissues, on the sterile wounds. In the first group, the study group, the patients' lesions with skin grafts were covered with a tulle dressing containing silverandin the other group, considered the control group, with normal bandage. The normal bandage was described by a non-medicated paraffin gauze dressing. The cotton fabric was impregnated with an ointment that combined white vaseline, microcrystalline hycrocarbon wax and diglycerol ester of mono- and dicarboxylic fatty acids.

\section{Results and discussions}

Twenty patients from our studycame from other medical centers and the rest were at first admission. In four patients, we started empirical antibiotherapy due to severe signs of infection at admission. Moreover, all wound cultures were positive, the most common bacteria being Staphilococcus aureus in 23 out of 30 cases, in 15 of the cases being meticilin resistant (MRSA). Other encountered bacteria 
were: Escherichia coli, Enterococcus faecalis and Pseudomonas aeruginosa. Due to the fact that skin grafting was desired systemic antibiotherapywas started.The median period of time of antibiotic administration was 7 days.

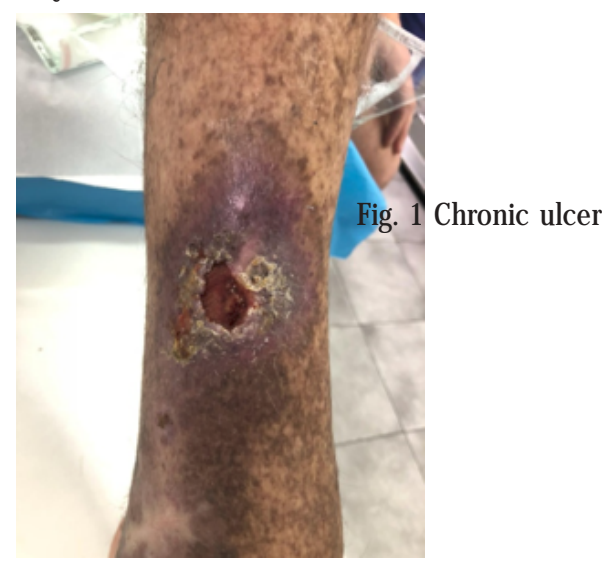

Prior the skin grafting, surgical removal of fibrin and devitalized tissue from the base and the borders of the ulcer was performed. In addition, occlusive dressings were used that promoted the optimal, moist environment, until the granulation tissue appeared. Before this second surgery, a hemoleucogram and total proteins were done trying to maintain a hemoglobin higher that $10 \mathrm{~g} / \mathrm{dL}$, proteins more than $4.5 \mathrm{~g} / \mathrm{dL}$ and albumin serum more than $2.5 \mathrm{~g} / \mathrm{dL}$ to promote skin graft integration.

In general, split thickness skin graft are used by plastic surgeons in burn reconstruction and to treat chronic or acute wounds [8], being one of the most widely used reconstructive techniques [9]. It is considered that the first procedure of skin grafting dates back to more than 2000 years ago, performed by the natives of India. But just in 1869, Reverdin described for the first time the pinch grafting [10].

The surgical intervention is a painful one, due to the harvesting part. The skin graft is harvested from the plane between the papillary and the reticular dermis. The sensory nerves remain exposed, causing important postoperative pain [8]. The local care is mandatory for the donor site wounds, preventing the pain, soreness, infection and scars. Usually, discomfort and pain appear in the donor site than in the recipient one. Based on the thickness of the split skin graft, the donor site lesion should entirely reepithelialize within 7 to 21 days [9]. Complications, such as donor site bleeding, infection and pruritis delay the healing [8], resulting extended patient hospitalization with higher cost of care [9]. For all patients the skin grafts were of medium thickness and they were harvested from the anterior part of the ipsilateral thigh. In all cases, the suture of the skin graft was performed with polypropylene, a monofilament materials with a smooth exterior to decrease tissue injury and bacterial harbours [11].

For the study group, silver dressing was used on the skin grafts, but also on the donor site.

The silver dressingis a nonadherent tulle with antibacterial properties. The support fabric is made of hydrophobic polyamide fibres coated with elemental silver. The thin tulle drapes easily and ensure close contact with the lesion. It is impregnated with a neutral ointment, without additives of vaseline or other paraffins, being soft, conformable and it can be removed painlessly. It is not cytotoxic and has an antibacterial effect for at least 7 days.

Elemental silver has an antibacterial effect against gram-negative and gram-positive bacteria, its efficiency agains microorganisms being known even in antiquity [12].

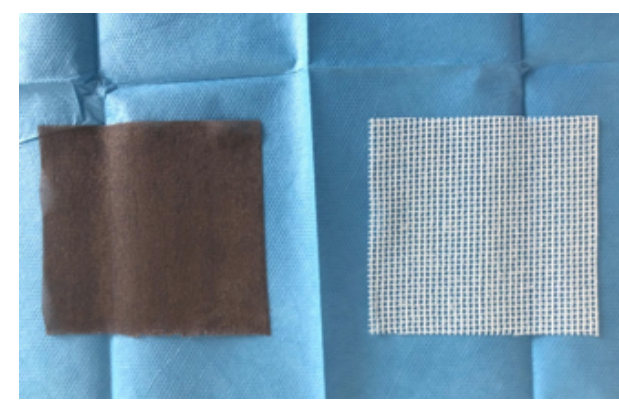

Fig 2. The two dressings used for the study: silver impregnated dressing (left) and paraffin gauze dressing (right)

In recent studies there are described the mechanisms through which silver dressing works, reducing pain and accelerating would healing, protecting the wound from infections. As a metal, silver, can rarely be absorbed by bacteria, instead can interact with the sulfhydryl groups in the respiratory enzymes of microorganisms, undermining their functions. Moreover, it can bind the bases of the bacterial DNAs, blocking its replication [13].

The silver tulle was changed for the first time after 5 days and after that was checked every 3 days in aseptic conditions to determine the evolution of the grafts until the grafts were integrated. The silver dressing offers air permeability, being tailored and changed with no difficulty, in the absence of residue [13]. Dressing of the study group was changed notably more comfortably. The skin grafts were totally integrated after 10-12 days. Negative pressure wound therapy with polyurethane foam can be used on the skin grafs that are covered with silver dressing [14].

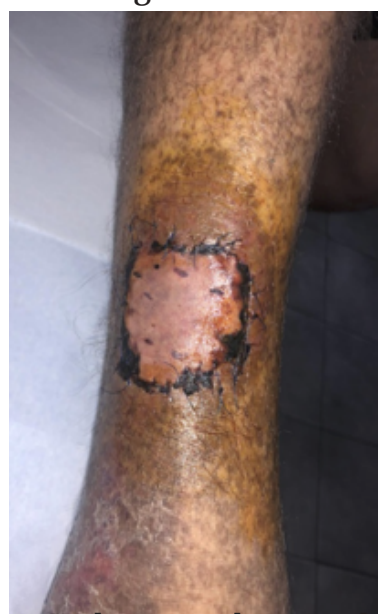

Fig. 3. The eighth day post skin grafting after coverage with silver dressing

In the control group, the grafts were integrated after 1517 days. For the donor site wounds, the silver dressing facilitated the healing in 7-8 days without any complications, reducing the pain in allpatients. In the control group, the donor site lesions re-epithelialized in 1415 days, donor site bleeding appeared in 12 cases.

\section{Conclusions}

Venous leg ulcers had a favorable outcome after the administration of antibiotic therapy, surgical debridement of the wound and coverage with a skin graft.

Skin grafting is a painfull proceduce, the dressings used postoperative provide shorter healing time and comfort. Even if, the ideal dressing, that produce rapid epithelialization, be pain free, infection free and cheap, does notexist, silver dressing are becoming an viable option for healing the wounds after skin harvesting.

\section{References}

1.ABBADE LP, LASTORIA S, IntJ Dermatol, 44, No. 6, 2005, p. 449-456. 2. DOGRA S, SARANGAL R, Indian Dermatol Online J, 5, No. 3, 2014, p. 400-407. 
3. RADUCU L, BALCANGIU STROESCU AE, STANESCU II , TANASESCU MA, COZMA CN , JECAN CR, BADITA DG, Rev. Chim. (Bucharest), 68, no. 9, 2017, p. 2112-2113.

4. VASUDEVAN B, Indian Dermatol Online J, 5, No. 3, 2014, p.366-370. 5. BALCANGIU-STROESCU AE, TANASESCU MD, DIACONESCU A, RADUCU L, BALAN DG, MIHAI A, TÃNASE M, STANESCU II, IONESCU D, Rev. Chim. (Bucharest), 69, no.11 , 2018, p: 3178-3182

6. KANJ OOR J R, Indian J Plast Surg, 44, No. 1, 2011, p. 109-111.

7. COZMA CN, RÃDUCU L, BALCANGIU-STROESCU AE, BADITA DG, JECAN CR, Romanian Journal of Infectious Diseases, 19, No. 4, 2016, p. 262-265

8. FEARMONTI RM, Wounds, 28, No. 7, 2016, p. 226-232

9. OLAWOYE OA, ADEMOLA SA, IYUN AO, MICHAEL AI, OLUWATOSIN

OM, Ann Burns Fire Disasters, 30, No. 2, 2017, p. 146-149.
10. HAMNERIUS N, WALLIN E, SVENSSON Å, STENSTRÖM P, SVENSJ Ö T, Eplasty, 16, No. 14, 2016.

11. JECAN CR,FILIP I, RADUCU L, HERNIC D, Key Engineering Materials, 638, 2015, p. 197-204

12. CONSTANDACHE O, CEREMPEI A, MURESAN R , SANDU ICA , MURESAN A, SANDU I, Mat. Plast., 52, No. 1, 2015, p. 24-27

13. YANG B, WANG X, LI Z, QU Q, QIU Y, PakJ Med Sci, 31, No. 6, 2015, p.1334-1339

14. AVINO A, JECAN CR, COZMA CN, BALCANGIU STROESCU AE, BALAN DG , IONESCU D, MIHAI A, TANASE M, RADUCU L, Mat. Plast., 55, no. 4, 2018, p. 603-605

$\overline{\text { Manuscript received:16.07.2018 }}$ 